\title{
System Information Audit with COBIT 4.1 and Balanced Scorecard Framework (Case Study: PT. Boga Dimsum Indonesia)
}

\author{
Handy Ghasali ${ }^{\mathrm{a}}$, Kevin Christianto ${ }^{\mathrm{b}}$ \\ aprogram Studi Sistem Informasi, Fakultas Teknologi dan Desain, Universitas Bunda Mulia, handyghasali@gmail.com \\ bProgram Studi Sistem Informasi, Fakultas Teknologi dan Desain, Unversitas Bunda Mulia, kchristianto@bundamulia.ac.id
}

\begin{abstract}
The advancement of information technology has led people more easily to connect with each other and provide value added in the form of efficiency and effectiveness that produce something for meeting purposes, record customer complaints, answer customer questions, convey information to customers, provide warranty, and seek profit by this utilization. The reason for the audit of SI in this study is PT. Boga Dimsum Indonesia where the company needs an audit on the inventory and accounting intregrated system because there is an error in the purchase application. In this research, the method used is qualitative research method that is research about descriptive research and tend to use analysis. The purpose of the audit is to know whether the information technology governance applied by PT. Boga Dimsum Indonesia has gone well. The research consists of 4 stages: planning, Field Work, Reporting, Follow Up. Based on the results of this study can be concluded that the IT functions contained in PT. Boga Dimsum Indonesia is not yet optimal.
\end{abstract}

Keywords: Audit, IS, COBIT 4.1, Balanced Scorecard, PT. Boga Dimsum Indonesia

\begin{abstract}
Abstrak
Kemajuan teknologi informasi telah mengantarkan umat manuasia semakin mudah untuk berhubungan satu dengan yang lainnya dan memberikan nilai tambah berupa efisiensi dan efektifitas yang menghasilkan sesuatu untuk keperluan rapat, mendata keluhan pelanggan, menjawab pertanyaan pelanggan, menyampaikan informasi kepada pelanggan, memberikan garansi, dan mencari keuntungan dengan pemanfaatan ini. Alasan dilakukannya audit SI dalam penelitian ini adalah PT. Boga Dimsum Indonesia yang dimana perusahaan membutuhkan audit pada program inventory and accounting intregrated system karena terdapat error pada aplikasi pembelian. Dalam penelitian ini, metode yang digunakan yaitu metode penelitian kualitatif yaitu penelitian tentang riset yang bersifat deskriptif dan cenderung menggunakan analisis. Tujuan dilakukannya audit adalah untuk mengetahui apakah tata kelola teknologi informasi yang diterapkan oleh PT. Boga Dimsum Indonesia sudah berjalan baik. Penelitian yang dilakukan terdiri dari 4 tahap yaitu planning (perencanaan), Field Work (Pemeriksaan Lapangan), Reporting (Pelaporan), Follow Up (Tindak Lanjut). Berdasarkan dari hasil penelitian ini dapat disimpulkan bahwa fungsi TI yang terdapat dalam PT. Boga Dimsum Indonesia belum optimal.
\end{abstract}

Kata kunci: Audit, SI, COBIT 4.1, Balanced Scorecard, PT. Boga Dimsum Indonesia.

(C) 2018 Jurnal RESTI

\section{Introduction}

The development of information technology is very fast. These advances have led people more easily to relate to one another. IT adds value in the form of efficiency and effectiveness that produces something PT. Boga Dimsum Indonesia produces and markets for meetings, records customer complaints, answers fresh and frozen foods, dimsum is a traditional Chinese customer inquiries, conveys information to customers, dish in the form of pastries, shrimp dumplings and guarantees, and benefits with this utilization. The spring rolls which are divided into categories of fry, service is certainly making the company will be closer steam, grill and microwave. At PT. Boga Dimsum to customers and customers will also feel happy Indonesia requires an audit of the inventory and because it served well by the company, therefore accounting intregrated system program which has an getting closer to get a profit that is easier to get [1]. error on the purchase application, the problem that Successful business by utilizing technology is occurs is in the first month, the staff input the stock of

inseparable from good IT governance. Some companies have sought to align IT strategies with their business strategies, and assess them to facilitate decision making on IT governance [2]

DiterimaRedaksi : 29-06-2018 | Selesai Revisi : 19-07-2018 | Diterbitkan Online : 24-07-2018 
goods that have been used, then the next month, the 2.5 Balanced Scorecard stock of goods is reduced according to the input by the staff, but in the second month the stock of goods reemerged with the stock of goods first input (stock of goods is still intact or not reduced at all) resulting in rechecking on the stock of the goods.

The author conducted an audit on PT. Boga Dimsum Financial perspective

Indonesia uses COBIT 4.1 to measure the IT performance contained within the company and the author also performs the company's performance measurement using Balanced Scorecard. The author uses the domain PO4, PO8, and AI6 and internal process perspectives. The author uses this domain to audit the application management at PT. Boga Dimsum Indonesia and also do service requests on the company. Therefore, the author wants to know whether PT. Boga Dimsum Indonesia is in accordance with the existence of applications that simplify the process of recording the purchase, sales and printing reports.

\section{Literature Review}

\subsection{Information System}

Information systems can be viewed in terms of physical and function. Information systems consist of hardware and software that useful to produce a product [3].

\subsection{Audit}

An information system audit is a process of collecting and evaluating evidence to determine whether the information system establishes and implements an adequate internal control system, all assets are well protected and not abused and ensured data integrity, reliability and effectiveness and efficiency of the organization of computer-based information systems [4].

\subsection{Audit Information System}

Balanced Scorecard is an integrated method and a variety of goals, performance measures, and organizational strategies. Balanced Scorecard translates all IT into 4 perspectives: financial, customer, internal business processes, and learning and growth [7]. The organization formulates the financial goals that the organization wants to achieve in the future then the financial goals are used as the basis for the other three perspectives in setting goals and measures.

\section{Customer Perspective}

The organization identifies the customers and market segments in which the organization will compete. The goal set in this perspective is the satisfaction of customer needs

Perspective Internal business processes (internalBusiness-process perspective)

Identify important processes of the organization to serve customers (customer perspectives) and organizational owners (financial perspectives) key components of internal business process perspective: innovation processes, operations processes, and aftersales services.

Learning and Growth perspective

Describes an organization's ability to create long-term growth. Reveals how important organizations to invest in infrastructure (workers, systems and procedures) if they want to achieve long-term financial growth goals [8].

\section{Research Methodology}

\subsection{Problem Identification}

The researcher identifies the problems that often occur Information technology can provide enormous benefits in the company by conducting interviews to the parties to the business world for companies that are able to who important related to the research, which is known compete in these competencies. The advantages of this based on the results of interview is often error occurs in computerized information system is to increase of the stocking goods input. In this company uses speed, accuracy in data processing information [5].

\subsection{COBIT 4.1}

COBIT 4.1 is a framework that consists of process domains that can be used to manage logical structure activity. The COBIT method is useful for dependable technologies for business and IT organizations. Control Objective for Information \& Related Technology (COBIT) is a set of best practice documentation for IT Governance that can assist auditors, users, and management, to bridge the gap between business risk, control requirements and technical IT issues [6].

$$
\text { sales, purchases and reports. }
$$

\subsection{Research objectives}

Once the problem is successfully identified, then the next stage is determine the purpose of research. In addition, researchers also determine the domain that use in accordance with the goals and results using the PO4, PO8, and AI6 domain. In PO4, IT organizations are defined taking into account requirements for staff, skills, functions, accountability, authority, roles and responsibilities, and oversight. A strategy committee ensures oversight of the IT board, and one or more steering committees in which business and IT 
participate in determining the priority of IT resources to between current maturity level and expected maturity appropriate based of the business needs. To ensure level.

timely business requirements support, IT must be involved in the relevant decision process. In PO8, a 3.6 Conclusion

QMS is developed and maintained that includes proven In the final stages of research is to draw conclusions processes and development standards and acquisitions. from the research that has been done in the company This is possible with planning, implementing and and provide recommendations or suggestions useful to maintaining QMS by providing clear quality improve the process of company performance. requirements, procedures, and policies. Quality management is crucial to ensuring that IT provides value for business, continuous improvement and transparency for stakeholders. In AI6, A QMS is developed and maintained that includes proven development processes and standards and acquisitions. This is made possible by planning, implementing and maintaining QMS by providing clear requirements, procedures, and quality policies. Quality management is critical to ensuring that IT provides value for business, continuous improvement and transparency for stakeholders [9].

\subsection{Document and interview confirmation}

At this stage, researchers do the confirmation of document in company by go to companies to get the document and information needed. Information obtained by conducting interviews. Interviews were conducted to 2 resource persons namely IT staff and manager. Researchers conducted interviews on IT and managers.

\subsection{Data Processing}

The results obtained from the interview then then the result of the interview is given the value based on the maturity level assessment on cobit 4.1. Maturity level in cobit 4.1 consists of 5 levels, namely level 0 is the company simply does not care about the importance of information technology to be managed well by management. Level 1 is the company is implementing information technology reactively in accordance with the sudden needs of the existing, without preceded by the planning. In level 2 there is a recurrent pattern in management related to information technology governance activities, but its existence has not been well-defined and formal so it is still inconsistent. In level 3 procedures are standardized, documented and then communicated through training. In level 4 management monitor and measures the appropriateness of the procedure and takes action if the process can not be worked out effectively. In level 5, information technology is used as an integrated way to automate workflow, provision of tools to improve quality and effectiveness and make companies quickly adapt.

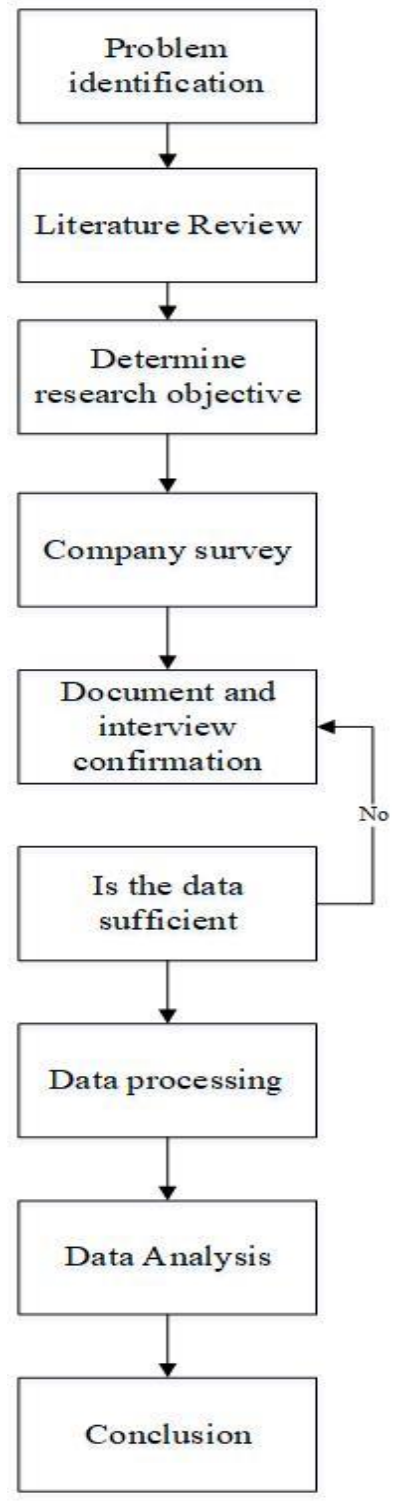

Figure 1. Research Flow Diagram [10]

\section{Results and Discussions}

\subsection{Data analysis}

The data has been obtained by analyzing by comparing PO4 Define The IT

Table 1. Table Maturity Level of PO4 domain the current maturity level obtained from the calculation and expected maturity level (the value expected by the company). After that, researcher calculate the gap 
Results of PO4 domain is the company does not ensure required for the supervision of IT quality management IT governance works well because it has only 1 IT system for the application is ensured good quality. The person and there is no responsibility for IT in the company has identified and maintained in the IT business to backup. In addition, there are no IT steering process to keep the system running properly. The committees, lack of IT staff, IT staff just as support, company will be better if there are procedures and and IT staff do not adequately ensure resources to documentation have been doing system development support the IT process because it still has errors in the by making the addition of function in the application application.

Recommendation on PO4, the company will be better to have a useful IT process to run IT plan, IT has good in communicating role and responsibility to all IT staff, then user and IT also better in doing data backup that once a month and also IT it would be better to have more than one person.

Table 2. Table Maturity Level of PO8 domain

\begin{tabular}{lcc}
\hline \multicolumn{1}{c}{ Sub domain } & Current Level & Status \\
\hline $\begin{array}{l}\text { PO8 Manage } \\
\text { Qualiy }\end{array}$ & 1,7 & Repeatable \\
\hline
\end{tabular}

Results of the PO8 domain is the company maintains Quality Management System maintenance on an ongoing basis, identifies the requirements and quality \begin{tabular}{cccc} 
AI6 Manage & Current Level & Status \\
\hline
\end{tabular} criteria, the quality management system reflects the Changes organizational structure that includes the roles and responsibilities by measuring the effectiveness and The result of the AI6 domain is that the company acceptance of the quality management system as it is already has procedures to handle standardized made according to user demand. With the existence of maintenance in changing applications, procedures, the quality management system to identify the systems and other parameters and platforms because it requirements and quality performance in accordance is more systematic, but the company does not change in with company standards. With the existence of the a structured way to determine the impact on the quality management system reflects the organizational operational system because it is all directed to the user. structure to include the roles and responsibilities The company ensures that IT changes are categorized, because the user has each job and supervise and prioritized and authorized because technology is more measure the effectiveness and acceptance of quality efficient and reporting faster. At the company there is management system that is useful to supervise the no documentation process to define the process of application is ensured good quality and the company defining, testing, documenting, approving changes that identifies the effectiveness, acceptance of quality do not follow the established process and also there is management system according to standards, procedures no tracking reporting in documenting the company and practices have existed in accordance with the because the company has never faced it. The company standards but there is no process documented and the updates appropriate system, documentation and company adopts and maintains quality standards for procedures every time a change is applied.

application development with programmer standards. Companies regularly maintain the overall quality of the system and encourage continuous improvements that are useful for maintance regularly but there is no improvement in case of problems. The company does not have quality management that is useful for planning and implementation of measurements to monitor the quality management system, the existence of measurement monitoring and recording of information used by the user to make correct repairs and prevention is done according to user error information which is useful to prevent errors against the user.

The recommendation for PO8 is the company has implemented a system made according to user demand, has followed the company standard and has each job
The recommendation on this domain is that the company is good at carrying out useful procedures for dealing with standardized improvements it would be better to give the time specified, the structured changes should be made by the authorities and the company has implemented useful IT changes to define processes to define, testing and documentation and recommended that the process be documented.

Table 4. Table Gap Analysis

\begin{tabular}{cccc}
\hline Domain & $\begin{array}{c}\text { Current } \\
\text { Level }\end{array}$ & $\begin{array}{c}\text { Expected } \\
\text { Level }\end{array}$ & Gap \\
\hline PO4 & 0,8 & 3 & 2,2 \\
PO8 & 1,7 & 3 & 1,3 \\
AI6 & 1,6 & 3 & 1,4 \\
\hline
\end{tabular}


In the PO4 domain, the gap result is 2.2 , with the current maturity level of 0.8 and the expected maturity level 3. In the PO8 domain, the gap result is 1.3 , with the current maturity level of 1.7 and the expected maturity level 3. In the AI6 domain, the gap result is 1.4 , with the current maturity level of 1.6 and the expected maturity level 3 .

Internal business process perspective to measure company performance is known from the business process value chain. The measurement used in this perspective is innovation with the aim to improve the company's profit and the form of innovation that is done is to create new food menus. The steps that must be done to improve the company's internal performance perspective internal process is to improve employee's work where employees can be added to improve the production process, so that all orders can be more quickly met. The process of operation is the process of creating and delivering a product or service. The related performance measurements in the operating process are grouped at times and costs.

Table 5. Table Linking IT Goals To IT Process

\begin{tabular}{lc}
\hline \multicolumn{1}{c}{ IT Goals } & IT Process \\
\hline $\begin{array}{l}\text { Respond to business } \\
\text { requirements that are aligned } \\
\text { with business strategy }\end{array}$ & PO4 \\
$\begin{array}{l}\text { Deliver projects on time and } \\
\text { within budget } \quad \text { information }\end{array}$ & PO8 \\
$\begin{array}{l}\text { Maintaining and processing } \\
\text { integrity and } \\
\text { infrastructure }\end{array}$ & \\
\hline
\end{tabular}

It can be concluded that business objectives and IT domain objectives obtained respond to business requirements that align with business strategy. What IT does by creating their own applications to assist the sales process, input process and PO4 purchase. The company delivers the project on time and within budget, which is the application development set by the PO8 company.

Maintain information integrity and infrastructure processing with information on sales applications, purchases and stock of goods according to company requirements on AI6 domain.

In figure 3 can be seen business objectives and IT objectives by using the internal perspective of the process on the Balanced Scorecard. From the company's business objectives is to innovate by creating new menus that reflect the company's business strategy. And companies improve the quality of their services by providing training to employees who are useful to improve service.

\begin{tabular}{|c|l|l|}
\hline $\begin{array}{c}\text { Balanced } \\
\text { Scorecard } \\
\text { Perspective }\end{array}$ & Business Goals & \multicolumn{1}{c|}{ IT Goals } \\
\hline \multirow{4}{*}{ Internal Process } & $\begin{array}{l}\text { Innovation made for } \\
\text { product innovation }\end{array}$ & $\begin{array}{l}\text { Respond to business } \\
\text { requirements that are } \\
\text { aligned with business } \\
\text { strategy }\end{array}$ \\
\cline { 2 - 4 } & $\begin{array}{l}\text { Improving employee } \\
\text { employee can } \\
\text { improve production } \\
\text { process to be fulfill }\end{array}$ & $\begin{array}{l}\text { Deliver projects on time } \\
\text { and within budget to } \\
\text { meet company standars }\end{array}$ \\
\cline { 2 - 4 } & $\begin{array}{l}\text { Improving the quality } \\
\text { of service process to } \\
\text { customer }\end{array}$ & $\begin{array}{l}\text { End user satisfication } \\
\text { with service offerings } \\
\text { and service level }\end{array}$ \\
\hline
\end{tabular}

Figure 3. Linking Business Goals to IT Goals

\section{Conclusion}

\subsection{Conclusion}

Based on the results of this study can be concluded that the domain PO8 is the highest level of domain maturity of 1.7 is Repeatable but intuitive where the company has developed but the company has no documentation but standard procedures. While the lowest value of the maturity level analysis results in $\mathrm{PO} 4$ domain of 0.8 Initial / Ad hoc where the company is aware of the existing problems but the process has not been balanced. Companies need to implement advice to identify internal processes in innovation, improve employee performance, production processes, build customer service that is useful to respond to customer feedback and company regulation rules.

\subsection{Suggestions}

Companies will need to recruit IT at least 2 people to speed up the process of fixing apps and bugs in order to process company work faster. Companies need to submit recommendations on each domain in order to achieve the level of maturity level at PT. Boga Dimsum Indonesia. Companies need to implement the advice given from the internal processes perspective on the Balanced Scorecard.

\section{References}

[1] Killian and Nursinita, "Peran Teknologi Informasi Dalam Komunikasi Antar Budaya Dan Agama," Jurnal Dakwah Tabligh, vol. 15, no. 2, pp. 159-176, 2014.

[2] F. P. Sihotang, "Penilaian Tingkat Kematangan Tata Kelola Teknologi Informasi menggunakan COBIT 4.1 pada PT XYZ," Jurnal RESTI, vol. 2, no. 1, pp. 375383, 2018.

[3] Iswandy And Eka, "Sistem Penunjang Keputusan Untuk Menentukan Penerimaan," Jurnal TEKNOIF, Vol. 3, Pp. 2338-2724, 2015. 
[4] N. Azizah, "Audit Sistem Informasi Menggunakan Framework Cobit 4.1 Pada E-Learning Unisnu Jepara," Jurnal Simetris, Vol. 8 , No. 1, 2017.

[5] Artha And U. Emilya, "Analisa Caats (Computer Assisted Audit Techniques)," 2014.

[6] Arliyana, "Audit Tata Kelola Sistem Teknologi Informasi Dan Komunikasi Perguruan Tinggi (Studi Kasus: STMIK Palangkaraya)," Ournal Speed - Sentra Penelitian Engineering Dan Edukasi, Vol. 7, No. 4, 2015.

[7] E. R. Nugrahayu And E. D. Retnani, "Penerapan Metode Balanced Scorecard Sebagai Tolok Ukur," Jurnal Ilmu \& Riset Akuntansi, Vol. 4, P. 10, 2015.

[8] H. Kurniawanto, "Pengaruh Keempat Perspektif Balanced Scorecard Terhadap Kinerja Seka Swalayan Sragen," Widya Sari , vol. 15, no. 2, pp. 61-84, 2013.

[9] T. I. R. K. Dewi, Linawati and I. M. O. Widyantara, "Audit Infrastruktur Aplikasi Pelayanan Publik Pemerintah," Teknologi Elektro, pp. 2503-2372, 2017.

[10] Jelvino And J. F. Andry, "Audit Sistem Informasi Absensi Pada PT. Bank Central Asia Tbk Menggunakan COBIT 4.1," Jurnal Teknik Informatika Dan Sistem Informasi, No. 2443-2229 , 2017. 